\title{
The Problem of Millenarism in India
}

\author{
By ERIK AF EDHOLM
}

In an article on medieval European millenarism and the comparative study of millenarian movements Norman Cohn asks: "Why [. . . ] has Indian society been almost free from millenarian movements-even though in the prophecy of Vishnu's avatar Kalki Hinduism has its own millenarian myth?"' Peter Worsley mentions the same problem in the last chapter of "The Trumpet Shall Sound": "[ . . ] Hinduism, appears to have been remarkably free from millenarist sects. [ . . ] One awaits with interest the explanation of this absence of millenarism from Hindu India [. . . .," ${ }^{2}$ And Wilhelm Mühlmann says in "Chiliasmus und Nativismus": "Aber das hinduistische und buddhistische Asien kennt keinen Chiliasmus. Wie kommt das?" 3

Though this question seems to have become a standing phrase in the literature on millenarism, there is also a work devoted to the collecting of "[...] all the available evidence on messianic movements that have occurred in India among various peoples in the course of several centuries." 4 This work is "Rebellious Prophets" by Stephen Fuchs. However, most of the movements discussed by Fuchs fall beyond the frame of traditional Hindu peasant society. The a priori most probable basis for meassianism in India is, according to Fuchs, the two main categories of "under-privileged" (i.e. oppressed) social groups: on the one hand the tribal peoples, on the other the untouchable castes and the other ritually impure castes. Accordingly, a large number of Fuchs' cases are movements among tribal groups; several of the remaining cases are examples of Muslim messianism.

\footnotetext{
Cohn $1970 a, 42 \mathrm{f}$.

2 Worsley, 232.

${ }^{3}$ Mühlmann, 365.

${ }^{4}$ Fuchs, xiii.
} 
But on the whole Hindu peasant society has hardly produced any cases of messianic-chiliastic mass movements. Obviously, the problem formulated by Cohn, Worsley, etc., is at least partially a real one.

\section{II}

A classical theme was revived by Jean de Meun in the "Roman de la rose" (ca 1270): the state of nature during the golden age. ${ }^{5}$ Through this work the theory of the original life of mankind in equality and prosperity was spread in French and several other popular languages. According to Jean de Meun the arrival of Poverty and various personified vices (Covetousness, Avarice, etc.) lead to an anarchic state, in which men were forced to elect a prince to rule over them: thus institutionalized oppression and exploitation was born.

From the end of the XIVth century a growing number of radical heretics saw their goal as the restoration of the state of nature. The communal ownership and the equality "when Adam dalf and Eve spun" were regarded as the law of God by popular preachers at the time of the English peasant rebellion in $1381 .{ }^{6}$ The same ideas were spread among the Bohemian Hussites in combination with the Joachimist prophecies on the imminent end of the existing age (consummatio seculi) and the advent of recreated realm (regnum reparatum), i.e. the Third Age, when the Holy Spirit shall rule. ${ }^{7}$ The arrival of the age of the millenium was identified with the reappearance of the golden age. These themes can be followed through the XVIth (The German peasant war, the Anabaptists of Münster) and the XVIIth (the English revolution) centuries. ${ }^{8}$

The myth of the recurrence of the golden age after a period of accelerating miseries ("messianic woes") in the near future is of course not peculiar to the chiliasm of the European later middle ages. On the contrary, it belongs to the basic eschatological themes of millenarism in general. ${ }^{9}$ These themes are found also in Hindu tradition. ${ }^{10}$

\footnotetext{
${ }^{5}$ Cf. Troeltsch, $410 \mathrm{ff}$; Cohn $1970 b, 195 \mathrm{ff}$.

${ }^{6}$ Cf. Cohn $1970 b, 198 \mathrm{ff}$.

${ }^{7}$ Cf. Reeves, Marjorie, $475 \mathrm{f}$.

${ }^{8}$ Cf. ib., 492; Cohn $1970 b, 287 \mathrm{ff}$; Hill, $118 \mathrm{f}$.

${ }^{9} \mathrm{Cf}$. Mühlmann, $288 \mathrm{ff}$.

${ }^{10}$ Cf. Abegg, 35 ff; Mühlmann, 298 ff; Sarkisyanz, $308 \mathrm{ff}$.
} 


\section{III}

In the Vanaparvan (148) of the Mahābhārata Hanumān describes the four ages of the world (yuga-s) to Bhima. During the first age, krtayuga, the eternal religion or right (dharmah sanätanah) was dominating. People neither bought nor sold, but got everything they needed through the power of thought. Illness, suffering and death did not exist. The four social estates (varna-s) lived together, devoted to their respective duties (svakarma). Though they had different customs (prthagdharma) they had but one religion (dharman ekam), one god (or one veda), one mantra and one ritual. They all had the same knowledge and all attained the highest goal.11

The way this ideal state degenerated is told in the Sāntiparvan (59). Originally there was neither royal power (rajjya) nor king ( $r \bar{a} j a)$ and there was no chastisement or authority (danda). But delusion (moha) centered the minds of men and the decline of dharma began. First greed (lobha) came, then lust ( $k \bar{a} m a)$ and passion ( $r \bar{a} g a)$. People no longer separated right from wrong, pure from impure. Seeing the decay of religion and right, the gods were seized with fear. Through their initiative Prthu was born and made a king to support dharma and punish the wrong-doers. ${ }^{12}$

Monarchy is glorified in contrast to anarchy also in the Santiparvan (67). It is said that long ago the strong devoured the weak like the fishes in the water, but the gods created kings to protect the people. ${ }^{13}$

While in the Vanaparvan (149) it is presupposed that the different occupations of the varna-s had always existed, this is not the case in another ancient description of krtayuga, found in the Vāyupurana and in the Brahmāndapurāna. ${ }^{14}$ The krtayuga passage in these two Purananas is closely related to the one in the Mārkaṇdeyapurāna, ${ }^{15}$ a shorter version occurs in the Visṇupurāna. ${ }^{16}$

According to the Mārkaṇdeyapurāna Brahmā created 1000 human couples from his mouth, 1000 from his breast, 1000 from his thighs and 1000 from his feet. In those days women did not menstruate and just two children were born to each couple. For 4000 years they lived in ever-lasting youth

\footnotetext{
${ }^{11}$ Cf. Mahābhärata 3.148.10 ff; Abegg, $11 \mathrm{f}$.

12 Cf. Mahäbhärata $12.59 .13 \mathrm{ff}$.

${ }^{13}$ Cf. Mahäbhärata 12.67.12 ff; Manusmrti 7.20; Arthaśāstra 1.13.

${ }^{14}$ Cf. Vàyupurāna 8.61; Brahmändapurāna 1.7.54f; Abegg, 17.

${ }^{15}$ Cf. Mārkandeyapurāna 49; Kirfel, 81 ff; Abegg, 15 ff.

${ }^{16}$ Cf. Viṣnupuräna 1.6.

3-752446 H. Biezais
} 
and happiness without enmity, in a mild climate without any need of shelter. They got their food from the wish-fulfilling trees (kalpavrkșa-s). But greed (lobha) drove them to appropriate the kalpavrkșa-s, which instantly died. Exposed to cold, heat, hunger and hostility, they began to build towns and forts, and they invented the systems of measurement. They also took possession of rivers, mountains, fields and plants, and their condition grew ever worse. Then Brahmā had to create the seventeen classes of cerealsagriculture and various kinds of work were invented. Brahmā gave men rules to live by according to justice and according to their qualities $(y a-$ thānyāyam yathāgunam). In the Vāyupurāna and the Brahmāṇdapurāna it is said that the strong became ksatriya-s, the truthful brahmans, the diligent vaisya-s and the indolent śüdra-s. Thus the four varna-s, their duties (karma) and their dharma had come into being. ${ }^{17}$

In the dominating epic-puranic tradition royal power is regarded as the result of the intervention of the gods during a period of decay following the golden age of krtayuga. In Buddhist literature, however, the theory of the social contract appears at an early stage: men voluntarily made an agreement to obey an elected ruler and give him a part of the agricultural product (rice) as a fee for his protection. ${ }^{18}$ The social contract is also briefly mentioned in Kauțilya's Arthaśāstra and in the Sāntiparvan (67), ${ }^{19}$ but only to strengthen monarchical ideology.

The dharma of the varna'-s and of the four stages of life (ásrama) ordained by Brahmā is gradually weakened during tret $\bar{a}-$, dvāpara- and kaliyuga. In the Vanaparvan (188) the sage Marrkandeya describes the decay during the last of the four ages of the world. Just one fourth of dharma remains. The varna structure is rapidly disintegrating and the whole world is turned upside down: the siudra-s no longer serve the brahmans but are their religious teachers. The whole world is barbarized (mlecchībhüta). Finally the last survivors will roam about screaming in their distress.

But fate (daiva) will turn favourable again and krtayuga will recommence with health and wealth. A brahman named Kalkī Viṣnuyaśas will be born in the village Sambhalagrāma. He will become a great hero and will win victory through dharma. As a world emperor (räjā cakravartî) he will an-

\footnotetext{
${ }^{17}$ Cf. Vàyupurāna $8.162 \mathrm{ff} ;$ Brahmānḍapurāna $1.7 .154 \mathrm{f}$.

${ }^{18} \mathrm{Cf}$. Sharma, $65 \mathrm{ff}$.

${ }^{19}$ Cf. Arthaśástra 1.13; Mahäbhärata 12.67; Sharma, 69 f, 74 f.
} 
nihilate the barbarians and bring peace to the world. A change of yuga-s will take place. In the new krtayuga the four varna-s will be reestablished..$^{20}$ The Brahmāndapurāna and other texts predict in a similar way that kaliyuga necessarily will come to an end and that krtayuga will automatically (sva$b h \bar{a} v \bar{a} d$ ) return. ${ }^{21}$ The Viṣnupurāna predicts that Kalkī as a part (amśa) of Vișnu will descend to the earth in order to destroy barbarians and evil-doers and to support dharma. ${ }^{22}$ In later texts, as the Bhāgavatapurāna. ${ }^{23}$ Kalkī is depicted on horseback and according to the Bhavișyapurāna he will sit on a divine steed with a sword in his hand. ${ }^{24}$ When the world has been destroyed through his yoga fire, the earth will be recreated as karmabhumi and the four varna-s will be reborn from Kalkī.

The most circumstantial version of the Kalki prophecy is found in the Kalkipurana. ${ }^{25}$ The struggle against the Jina (=the Buddha) and the Buddhists of Kikata occupies an important position in this text, as does the battle with the ruler of Bhallăta named Śaśidhvaja ("Moon banner", perhaps an allusion to the Muslims). ${ }^{26}$

The hostility to the Buddhists and other heretics is just one expression of the strong brahmanic tendency in the epic-puraninic descriptions of the golden age and the expected messianic epoch. As a contrast to the dissolution of the social hierarchy during kaliyuga, when śüdra-s and barbarians claim political power and religious authority, stands the ideal varnāasramadharma ordained by Brahmā and reestablished by Kalkī. The brahman Kalki will not come to reinstate the primeval equality, but to reinforce the hierarchy. The dominating trend in these texts is reactionary, ${ }^{27}$ and only behind it might a suppressed egalitarian ideal be discerned. This specific ideological form given to the millenarian themes does not alter the fact that these themes were at hand and could as well have been made to express an opposite ideology. Evidently it was not the lack of millenarian or messianic mythologems which prevented the rise of movements with an egalitarian

\footnotetext{
${ }^{20}$ Cf. Mahābhārata 3.188f; Abegg, $57 \mathrm{ff}$.

${ }^{21}$ Cf. Kirfel, 520.

${ }^{22}$ Cf. Vișnupuräna $4.24 .98 \mathrm{ff}$; Abegg, $63 \mathrm{f}$.

${ }^{23}$ Cf. Bhāgavatapurāna 12.2.16ff; Abegg, $64 \mathrm{f}$.

${ }^{24}$ Cf. Bhavisyapurāna, Pratisargaparvan $4.26 .1 \mathrm{ff}$.

${ }_{25} \mathrm{Cf}$. Abegg, $71 \mathrm{ff}$.

${ }^{26}$ Cf. ib., 122 note.

27 Cf. Mühlmann, 300.
} 
chiliastic ideology. Is then the reason to be found in the prevalent Weltanschauung as a whole? This is not very probable as the brahmanic Weltanschauung did not attain total dominance. The main parts of the epicpurānic literature and other brahmanic texts merely reflect the world view of the religious elite.

\section{IV}

As an answer to the question why Indian society has been almost free from millenarian movements, Norman Cohn suggests that perhaps "[...] a series of reincarnations ending infallibly in Nirvana offers the individual a more convincing prospect of total salvation than does the Christian hope (which must remain most uncertain) of heaven?" ${ }^{\prime 28}$ It is not quite clear why Cohn finds the Hindu alternative more convincing: only through his own effort (or through the grace of god) the Hindu can gain release and beatitude. But of course the existential situation of the individual is not identical according to Hindu and Christian tradition.

An argument related to Cohn's is used by Max Weber. He states that Hinduism does not know of a "last day", i.e. a definite ending point of a linear process of time. He continues: "Karma doctrine transformed the world into a strictly rational, ethicially-determined cosmos; it represents the most consistent theodicy ever produced by history. The devout Hindu was accursed to remain in a structure which made sense only in this intellectual context [. . .]." 29 The rationality of this world view did not, however, prevent the rise within Hinduism of the bhakti religions according to which the grace of the personal god is necessary for salvation. And the subtleties of the rational theodicy is anyway, as Weber himself admits, usually not understood by the devout Hindu.

Wilhelm Mühlmann combines the same type of argument with a historical thesis: "Der Hinduismus und Buddhismus sind mystische Religionen, Judentum, Christentum und Islam dagegen prophetische. Aus diesem Gegensatz resultiert ein radikal verschiedenes Verhältnis zur 'Zeit' und zur Geschichte. Die mystischen Religionen haben ein Verhältnis zur Geschichte eigentlich überhaupt nicht. Ewig wiederholt sich das Gleiche. [...] Die Tendenz zum Aufruhr ist durch die jüdisch-christliche Apokalyptik in die

${ }^{28}$ Cohn 1970 a, 43.

${ }^{29}$ Weber, 121. 
Welt gekommen. Seither gibt es ein Prinzip der Empörung." ${ }^{30}$ According to Mühlmann this is the reason why the mythologems of the golden age and its reappearance, which are found both in Hindu and Christian tradition, are given contrasting ideological contents. In the Hindu case the point of view is "retrospective", in the Christian case "prospective". ${ }^{31}$ As Mühlmann's thesis is of an historical character, straining the uniqueness of the Jewish-Christian-Muslim tradition, it is possible to raise other objections to it, than to the arguments referring solely to the inherent qualities of the brahmanic Weltanschauung.

Mühlmann's theory is that Hindu and Buddhist Asia knows of no chiliasm, ${ }^{32}$ because its traditions lack the basic "prophetic" attitude. ${ }^{33}$ China is hardly mentioned by Mühlmann, which is odd, as he cannot possibly be ignorant of the influence of millenarism in Chinese history.

\section{V}

In the same way as in the Hindu tradition, the millenarian and messianic ideas in Mahāyana Buddhism are integrated in a world view based on the theodicy of the karma doctrine; in the same way as in Hinduism this theodicy is softened by the faith in personal saviours. The secret societies and chiliastic movements in China appropriated the millenarian and messianic myths and gave them a rebellious meaning. At the same time Buddhist ideas were combined with Taoist and Confucian elements ("the mandate of Heaven").

The ideology of the "Yellow Turbans", who rebelled in 184 A.D. under the leadership of the thaumaturge Chang Chio was dominated by Taoism, though there are traces of Buddhist influence in T'ai-p'ing-ching, the text on which they probably based their religious tenets. This text predicts that the "peace air" is to arrive, and that the spirit will descend in a virtuous ruler. It was proclaimed at the time of the rebellion that the Yellow Heaven was to be erected and that great happiness would come to the earth in the year chia-tzu (184 A.D.). ${ }^{34}$

\footnotetext{
${ }^{30}$ Mühlmann, $365 \mathrm{f}, 371 \mathrm{f}$.

${ }^{31}$ Cf. ib., 297.

${ }^{32}$ Cf. ib., 365, 396.

${ }^{33}$ Cf. ib., 300 .

${ }^{34} \mathrm{Cf}$. Shih, $164 \mathrm{ff}$; Bauer, $173 \mathrm{ff}$.
} 
The sects of the Buddhas Maitreya ${ }^{35}$ and Amitäbha played a significant role in many popular uprisings in China. An edict of 715 states that "certain monks in white robes and wearing long hair pretended that Maitreya has descended and started heretic rumors [...]". ${ }^{36}$ The rebellions associated with the hope of the arrival of Maitreya, the Buddha of the future, and the restoration of dharma were frequent at the end of the Mongol Yüan dynasty. The Maitreya societies had partially merged with the White Lotus society based on the cult of Amitābha and influenced by Manichaeism. ${ }^{37}$ The Ming dynasty, established after the fall of the Mongols, got its name from the title ming-wang, i.e. the "enlightened ruler" who according to the White Lotus society would appear at the time of Maitreya' descent from the Tușita heaven. ${ }^{38}$

It is not possible, nor is it necessary, to go into any more details here. China is the classical country of peasant rebellions, and most of the popular uprisings were associated with the secret societies, which were the transmitters of the rebellious ideologies ${ }^{39}$ As in the heretic ideologies of the European popular rebellions there are both "retrospective" and "prospective" elements: "The peasant ideology of revolt is full of religous feeling and nostalgia, looking back to a time of primitive justice $[\ldots]$ peasant revolts were above all fed by popular and dissident cults associated with Taoism and Buddhism. They were permeated by Buddhist millenarism inspired by the Maitreya Buddha." 40

What then is the difference in this respect between the "mystic" religions of East (and South) Asia and the "prophetic" Jewish-Christian-Muslim tradition? The presence or absence of "prophecy" is of course a matter of definition. But anyway the lack of "prophets" (defined in some rigorous way) is not an "explanation" of the absence of millenarian mass movements from Hindu India-its just another way to pose the problem. China, too, has been declared to lack ("ethical") prophecy, ${ }^{41}$ but there we find chiliastic movements. Moreover, there has always been an abundance of

\footnotetext{
35 On Maitreya cf. Abegg, $145 \mathrm{ff}$.

${ }^{36}$ Quoted in Shih, 188.

${ }^{37}$ Cf. ib., $188 \mathrm{ff}$; Bauer, $308 \mathrm{f}$; Ch'en, $426 \mathrm{ff}$.

${ }^{38}$ Cf. Ch'en, $434 \mathrm{f}$.

${ }^{39}$ Cf. Yang, 218 ff; on European sects: Worsley, 317; Cohn $1970 a, 37$.

${ }^{40}$ Chesneaux, 16.

${ }^{41}$ Cf. Yang, 239 (criticism of Weber).
} 
charismatic leaders in India, who could have used the millenarian myths in the same way as the Chinese leaders of secret societies and peasant wars. In India there even existed armed religious orders, militant ascetics, ${ }^{42}$ whose most reputed exploit was the sannyāsi rebellion against the British (1772-73).

\section{VI}

The sannyāsì rebellion is an example of movements directly provoked by an economic and political crisis, by a "conjuncture". ${ }^{43}$ Such crises were the general background of most European and Chinese millenarian mass movements. ${ }^{44}$ India has hardly been less afflicted by economic and social crises, and thus the occasions for chiliastic "crisis rebellions" have been no fewer.

Peter Worsley has remarked that it is close to a tautology to say that historically important millenarian movements are movements of the disinherited; their historical importance is dependant on their ability to mobilize the masses..$^{45}$ But the question whether the chiliastic sects taking part in popular rebellions usually have formed a leading avantgarde or a noisy tail without real support among the majority of the rebellious population, ${ }^{46}$ is not the most important one. The decisive point is that when millenarism has been widely spread and has played a historically significant role, it has been associated with mass movements among peasants, artisans and (lumpen-) proletariat. The lack of influential chiliastic movements in Hindu traditional rural society is, in this perspective, another aspect of the weakness of peasant mass movements. The various forms of peasant political activity and organization have to be studied in their total social context; in this way it might be possible to explain, why radical chiliasm seems to be lacking even in the known cases of "crisis rebellion" in pre-colonial India. Some revolts of this type did occur in the Mughal empire.

The feudal-bureaucratic elite of Mughal India, the jāgir $r \bar{a} r$-s, were supported by prebends. The mounting economic pressure provoked a serious conflict between the jāgir $\bar{a} \bar{a} r$-s and the local elite groups, the zamindār $r$-s, who also claimed a substantial part of what the peasants produced. In the

\footnotetext{
42 Cf. Farquhar, $431 \mathrm{ff}$,

${ }_{43}$ Cf. Mousnier, 320.

${ }^{44}$ Cf. ib., 350; Yang, $224 \mathrm{ff}$.

${ }_{45}$ Cf. Worsley, 318.

${ }^{46}$ Cf. Cohn $1970 a, 37 \mathrm{ff}$.
} 
second half of the XVIIth century the zamindār-s acted as leaders of several peasant uprisings directed against the central state authority and the $j \bar{a} g \bar{\imath} r$ $d \bar{a} r-\mathrm{s} .{ }^{47}$

W. C. Smith says about these rebellions that "[...] in Mughal times no class revolt attained significant proportions that did not have a religious ideology to sustain it". ${ }^{48}$ To a great deal, however, this is still a matter of inquiry. Some of these uprisings were rapidly crushed and their religious tenets are not very well known. Anyway, radical millenarism is hardly to be expected in movements dominated by local elite groups (as among the Marathas), even if there certainly were egalitarian tendencies. ${ }^{49}$

\section{VII}

To determine those general characteristics of traditional Hindu society which can contribute to an explanation of the relative unimportance of peasant rebellions ${ }^{50}$ and the lack of chiliastic mass movements, is not a problem to be solved within the field of the history of religions. I will just point to a few factors.

According to a common type of general analysis the Indian traditional peasant society is characterised by a combination of "organic solidarity" (to use the Durkheimian expression) within the local community with a segmentary structure of the society as a whole, i.e. the relations between the local communities is based on "mechanic solidarity". If we try to look at matters in a somewhat more concrete way, we can separate two levels that have to be analysed:

1) the caste hierarchy and the patron-client relations;

2) the local and regional segmentation, the "cellular" structure. ${ }^{51}$

At the same time it is essential to investigate the alternative channels for social change and religious renewal within the Hindu peasant society. One such channel is caste mobility, which made an adaptation possible between a group's position within the local (ritual) caste hierarchy and its

\footnotetext{
${ }^{47}$ Cf. Habib $1965,71,74$.

${ }^{48}$ Smith, 28.

49 Cf. ib., 39.

${ }^{50} \mathrm{Cf}$. Moore, $453 \mathrm{ff}$.

${ }^{51}$ Cf. Leach, 24; Worsley, $236 \mathrm{ff}$.
} 
actual economic and political power. ${ }^{52} \mathrm{~A}$ militant peasant group thus could be established as a local elite group and attain rājput status. Mobility has also been combined with migration. A possible reaction to pressure of land rent and taxes was that the peasants left and settled in a new area. ${ }^{53}$

Another channel was opened through the religious sects. Opposition to brahmanical orthodoxy has taken many forms (even if we do not take Buddhism, Jainism and the imported religions into consideration). Among them are:

1) materialistic hedonism (lokāyata);

2) the ritual anti-structure of tantrism (vāmācāra) and the theory of the complete freedom from all restrictions of the perfect (siddha);

3) the theistic movements of salvation (bhakti).

But as just the tantric criticism of the ritualism of orthodox brahmanical tradition was combined with the establishing of a new ritualism, so the bhakta criticism of the caste system was combined with the constituting of new castes. The egalitarian message of the bhakti saints, disputing the hierarchy, did not preclude that the salvationist sects did adapt to the caste system. ${ }^{54}$ The religious movements contributed to and gave ideological form to adjustments within the existing social structure. Obviously there was little need for millenarism in this process.

\section{Bibliography}

Abegg, E., 1928, Der Messiasglaube in Indien und Iran. Berlin \& Leipzig.

Arthaśästra, 1960, The Kauțiliya Arthaśástra 1. A Critical Edition with a Glossary. By R. P.

Kangle. University of Bombay Studies. Sanskrit, Prakrit and Pali 1. Bombay.

Bauer, W., 1971, China und die Hoffnung auf Glück. München.

Bhāgavatapurāna, 1963, Śrīmadbhāgavatamahāpurāna. Gorakhpur.

Bhavisyapurāna, 1959, Bhavișya mahāpurāna. Bombay.

Brahmāndapurāna, 1973, Brahmạndapurāna. Ed. by J. L. Shastri. Delhi.

Ch'en, K., 1972, Buddhism in China. Princeton.

Chesneaux, J., 1973, Peasant Revolts in China 1840-1949. London.

Cohn, N., $1970 a$, Medieval Millenarism: Its Bearing on the Comparative Study of Millenarian Movements. Millenial Dreams in Action, New York.

- $1970 \mathrm{~b}$, The Pursuit of the Millennium. London.

Farquhar, J, 1925, The Fighting Ascetics of India. Bulletin of the John Rylands Library 9.

\footnotetext{
${ }_{52}$ Cf. Mandelbaum, 441.

${ }^{53}$ Cf. Habib 1963, 115 ff.

${ }^{54}$ Cf. Mandelbaum, $523 \mathrm{ff}$.
} 
Fuchs, S., 1965, Rebellious Prophets. London.

Habib, I., 1963, The Agrarian System of Mughal India. Bombay.

- 1965 The Social Distribution of Landed Property in Pre-British India. Enquiry 2.

Hill, C., 1973, The World Turned Upside Down. New York.

Kirfel, W., 1927, Das Purāna Pañcalaksana. Leiden.

Leach, E., 1959, Hydraulic Society in Ceylon. Past and Present 15.

Mahäbhärata, 1927-66 The Mahābhärata. Critically ed. by V. S. Sukthankar, S. K. Belvalkar and P. L. Vaidya. Poona.

Mandelbaum, D., 1972, Society in India 2. Berkeley.

Manusmṛti, 1970, The Manusmrịti. Ed. by G. Sāstrī Nene. The Kashi Sanskrit Series 114. Varanasi.

Märkaṇdeyapurāna, s.a., Srīmārkaṇḍeyapurāna. Bombay.

Moore, B., 1969, The Social Origins of Dictatorship and Democracy. Harmondsworth.

Mousnier, R., 1967, Fureurs paysannes. Paris.

Mühlmann, W., 1961, Chiliasmus und Nativismus. Berlin.

Reeves, Marjorie, 1969, The Influence of Prophecy in the Later Middle Ages. Oxford.

Sarkisyanz, E., 1955, Russland und der Messianismus des Orients. Tübingen.

Sharma, R., 1968, Aspects of Political Ideas and Institutions of Ancient India. Delhi.

Shih, V., 1956, Some Chinese Rebel Ideologies. T'oung Pao 44.

Smith, W., 1946, Lower-class Uprisings in the Mughal Empire. Islamic Culture 20,1.

Troeltsch, E., 1923, Die Soziallehren der christlichen Kirchen und Gruppen. Gesammelte Schriften 1. Tübingen.

Vãyupurāna, s.a., Śrimadvāyumahàpurāna. Bombay.

Weber, M., 1967, The Religion of India. New York and London.

Viṣnupurāna, 1960, Śrísiriviṣnupurānana. Gorakhpur.

Worsley, P., 1970, The Trumpet Shall Sound. London.

Yang, C., 1967, Religion in Chinese Society. Berkeley and Los Angeles. 